\title{
DEPRESSIVE DISORDERS IN TYPE 2 DIABETES - INITIAL REPORTS
}

\author{
Katarzyna Wojtas ${ }^{1 A, C, D, E, F}$, Katarzyna Anna Czyżowicz ${ }^{1 A, C, D, E}$, Iwona Sibiga ${ }^{2 B, C, D}$, Zofia Musiał ${ }^{1 C, D, E}$
}

'Department of Clinical Nursing, Institute of Nursing and Midwifery, Faculty of Health Sciences, Jagiellonian University Medical College, Krakow, Poland

${ }^{2}$ Clinic of Gastroenterology, Endocrinology, and Internal Diseases, Military Institute of Medicine, Warsaw, Poland

Authors' contribution:

A. Study design/planning $\bullet$ B. Data collection/entry $\bullet$ C. Data analysis/statistics $\bullet$ D. Data interpretation $\bullet$ E. Preparation of manuscript $\bullet$ F. Literature analysis/search $\bullet$ G. Funds collection

\author{
Address for correspondence: \\ Dr. Katarzyna Wojtas \\ Department of Clinical Nursing \\ Institute of Nursing and Midwifery \\ Faculty of Health Sciences \\ Jagiellonian University Medical College \\ 25 Kopernika St., 30-501 Krakow, Poland \\ e-mail: katarzyna.wojtas@uj.edu.pl \\ SUBMITTED: 25.03 .2020 \\ ACCEPTED: 13.04 .2020 \\ DOI: https://doi.org/10.5114/ppiel.2020.96094
}

\begin{abstract}
Introduction: Diabetes patients experience burdens associated with adherence to treatment, self-control, and taking preventive measures against diabetic complications. These can contribute to the development of depressive disorders. Aim of the study: To assess the occurrence and severity of depressive disorders and factors connected with them among diabetes type 2 patients aged 35-64 years.

Material and methods: The research was done with the use of a diagnostic survey method among 70 patients in the Metabolic Disease Department of the University Hospital in Krakow. The Beck Depression Inventory and the authors' own interview questionnaire were used. Statistical analysis was carried out using Statistica 13.1, and $p<0.05$ was the significance level.

Results: The average number of points in the Beck Depression Inventory was 12.81 (moderate level of depressive disorders). Greater severity of depressive disorders was present in people who were professionally inactive, who defined their monthly income as insufficient, who felt uncertainty after diabetes diagnosis, whose treatment included both diet and insulin intake, who had problems with foot care, and who did not follow the diabetes treatment principles. The respondents who declared lack of support from their spouses felt the impact of diabetes on their mental well-being and confirmed the need for help in connection with the disease and had increased levels of depressive disorders.

Conclusions: Due to the occurrence of depressive symptoms among diabetes patients it is necessary to conduct screening research for depressive disorders. It should be an indispensable element of the therapeutic team's activities. Key words: Beck Depression Inventory, depressive disorders, diabetes.
\end{abstract}

\section{INTRODUCTION}

Diabetes belongs to metabolic diseases and is characterised by chronic glucose disturbance (hyperglycaemia) causing many complications [1].

The need to change the patient's lifestyle due to the need for systematic self-monitoring, compliance with dietary recommendations, and taking actions to prevent early and late diabetes complications [2], as well as the lack of prospect for a cure [3], can affect the well-being of the sick person and contribute to the development of depressive disorders. Some studies show that depression is a common phenomenon among people with diabetes that may have a recurrent tendency [4]. The course of depressive disorders includes a number of symptoms that require medical intervention, including lower mood, slower psychomotor drive, and sleeping disorders [5].
Diabetes, as a chronic disease, often causes dependence among family members [6], who are most often sources of support and assistance for the patient.

\section{AIM OF THE STUDY}

The aim of the study was to assess the occurrence and severity of depressive disorders and related factors among patients aged 35-64 years diagnosed with type 2 diabetes.

\section{MATERIAL AND METHODS}

The study was conducted in the Department of Metabolic Diseases of the University Hospital in Krakow, after obtaining the consent of the Bioethics Committee (1072.6120.192.2017) and the consent of each of the 70 qualified patients diagnosed with type 2 diabetes. 
Subjects had to meet the criteria of age (35-64 years old) and duration of hospitalisation (over three days). Coexistence of neoplastic disease, dementia, and radical treatment of diabetes complications (limb amputation) were the criteria for exclusion from the study. The research was carried out using the diagnostic survey method, the interview technique, and a scale. In order to assess the severity of depressive disorders, the Beck Depression Inventory was used allowing patients to express their feelings on a four-point scale. According to the key - the higher the point values obtained in the inventory, the greater the severity of depressive disorders [7]. The second research tool - the author's interview questionnaire - allowed sociodemographic data and data on the course of diabetes to be obtained.

The study group comprised $42.9 \%$ women and $57.1 \%$ men; the average age was 55.66 years $( \pm 7.03)$. $74.3 \%$ of the respondents remained in permanent relationships, and $40.0 \%$ of the respondents lived with their spouse or partner. The biggest group of the respondents had basic vocational education (42.9\%). Current professional activity was confirmed by $32.9 \%$ of the participants. In turn, $12.9 \%$ of people participating in the survey described their own monthly income as sufficient. $58.6 \%$ of respondents indicated a city as their place of residence. The average duration of illness in the study group was $10.58 \pm 7.61$ years.

The statistical analysis of the data was carried out in the Statistica 13.1 package, and the tests of Shapiro-Wilk, U Mann-Whitney, and ANOVA Kruskal-Wallis were used. Numeric variables are presented as arithmetic average, standard deviation, median, minimum, maximum, the lower and upper quartiles. Correlations were established on the basis of Spearman's rank correlation coefficient. Statistical significance was assumed at $p<0.05$.

\section{RESULTS}

\section{Results of Beck's Depression Inventory}

The average number of points obtained by the examined patients in the Beck Depression Inventory was
12.81 points, with the standard deviation $\mathrm{SD}=9.84$ points, which means a moderate severity of depressive disorders.

\section{Correlations between the Beck Depression Inventory results and demographic variables}

Greater severity of depressive disorders was confirmed by people who were professionally inactive $(p=0.012)$, in contrast to working people, as well as patients by whom monthly income was defined as insufficient or rather insufficient $(p=0.006)$. There was no significant relationship between the severity of depressive disorders and gender, age, marital status, place of residence, education, and source of income $(p>0.05)$. The results shown in Table 1 .

\section{Correlations between Beck's Depression Inventory results and selected variables related to the course of diabetes}

Selected variables related to the course of diabetes were grouped into the following categories: subject's reactions after the diagnosis of the disease and its impact on the emotional sphere, current treatment, support in the disease, and rules of conduct and care in diabetes.

Data analysis showed a statistically significant positive relationship between the severity of depressive symptoms among the subjects and the occurrence of a feeling of uncertainty after hearing the diagnosis $(p=0.048)$. There was no relationship between the severity of depressive disorders and dejection, despair, fright, fear, nervousness, anxiety, anger, disbelief, denial, panic, and indifference felt in this situation $(p>0.05)$.

The correlation between the current treatment of the subjects and the severity of depressive disorders was statistically significant. It was shown that greater severity of the above disorders was present in people whose treatment included simultaneous insulin intake and diet compared to patients whose treatment was different $(p=0.012)$.

Table 1. Socio-demographic variables vs. severity of depressive disorders among the respondents

\begin{tabular}{|c|c|c|c|c|c|c|c|c|c|c|}
\hline \multicolumn{2}{|c|}{ Socio-demographic variables } & \multicolumn{9}{|c|}{ Beck Depression Inventory results } \\
\hline & & $n$ & $\bar{x}$ & SD & $\mathrm{Me}$ & Min. & Max. & Q1 & Q3 & $p$ \\
\hline \multirow{2}{*}{$\begin{array}{l}\text { Undertaking } \\
\text { professional activity }\end{array}$} & No & 41 & 15.02 & 9.97 & 12.00 & 4.00 & 45.00 & 8.00 & 19.00 & 0.012 \\
\hline & Yes & 29 & 9.69 & 8.90 & 9.00 & 0.00 & 34.00 & 3.00 & 12.00 & \\
\hline \multirow{4}{*}{$\begin{array}{l}\text { Monthly income } \\
\text { rating }\end{array}$} & Insufficient & 21 & 16.19 & 9.70 & 14.00 & 4.00 & 36.00 & 8.00 & 21.00 & 0.006 \\
\hline & Rather insufficient & 13 & 17.00 & 10.52 & 11.00 & 8.00 & 34.00 & 9.00 & 26.00 & \\
\hline & Rather sufficient & 27 & 9.04 & 9.30 & 7.00 & 0.00 & 45.00 & 3.00 & 11.00 & \\
\hline & Sufficient & 9 & 10.22 & 6.16 & 12.00 & 1.00 & 18.00 & 5.00 & 15.00 & \\
\hline
\end{tabular}

$n$ - number of observations; $\bar{x}$ - arithmetic average; SD - standard deviation; Me - median; Min. - minimum; Max - maximum; Q1 - lower quartile; Q3 - upper quartile; $p$ - significance level $p<0.05$ 
Table 2. Variables related to the course of the disease vs. severity of depressive disorders among the subjects

\begin{tabular}{|c|c|c|c|c|c|c|c|c|c|c|}
\hline \multicolumn{2}{|c|}{ Variables related to the course of diabetes } & \multicolumn{9}{|c|}{ Beck Depression Inventory results } \\
\hline & & $n$ & $\bar{x}$ & SD & Me & Min. & Max. & Q1 & Q3 & $p$ \\
\hline \multirow{2}{*}{$\begin{array}{l}\text { Uncertainty as a reaction after } \\
\text { hearing the diagnosis }\end{array}$} & Yes & 10 & 18.00 & 10.42 & 15.50 & 3.00 & 36.00 & 12.00 & 26.00 & 0.048 \\
\hline & No & 60 & 11.95 & 9.55 & 10.00 & 0.00 & 45.00 & 5.00 & 17.00 & \\
\hline \multirow{2}{*}{$\begin{array}{l}\text { Current diabetes treatment: insulin } \\
\text { therapy and diet }\end{array}$} & Yes & 55 & 14.29 & 10.19 & 12.00 & 1.00 & 45.00 & 6.00 & 19.00 & 0.012 \\
\hline & No & 15 & 7.40 & 6.01 & 8.00 & 0.00 & 18.00 & 2.00 & 11.00 & \\
\hline \multirow[t]{2}{*}{ Need of assistance from others } & Yes & 24 & 18.92 & 10.74 & 18.00 & 4.00 & 36.00 & 9.50 & 29.50 & $<0.001$ \\
\hline & No & 46 & 9.63 & 7.69 & 8.50 & 0.00 & 45.00 & 4.00 & 12.00 & \\
\hline \multirow{2}{*}{$\begin{array}{l}\text { Compliance with diabetes } \\
\text { management principles }\end{array}$} & Yes & 41 & 11.12 & 9.72 & 8.00 & 0.00 & 36.00 & 4.00 & 16.00 & 0.016 \\
\hline & No & 29 & 15.21 & 9.66 & 12.00 & 1.00 & 45.00 & 10.00 & 19.00 & \\
\hline \multirow{2}{*}{$\begin{array}{l}\text { Impact of diabetes on mental } \\
\text { well-being }\end{array}$} & Yes & 44 & 15.70 & 9.44 & 13.50 & 1.00 & 36.00 & 9.00 & 20.50 & $<0.001$ \\
\hline & No & 26 & 7.92 & 8.61 & 6.00 & 0.00 & 45.00 & 3.00 & 11.00 & \\
\hline \multirow{2}{*}{$\begin{array}{l}\text { Difficulties in foot care in compliance } \\
\text { with guidelines in force }\end{array}$} & $R$ & & & & & & & & & \\
\hline & 0.24 & & & & & & & & & 0.041 \\
\hline
\end{tabular}

$n$ - number of observations; $\bar{x}$ - arithmetic average; Me - median; Min - minimum; Max - maximum; Q1 - lower quartile; Q3 - upper quartile; $S D$ - standard deviation; $p$ - significance level of differences; $R$-Spearman's rank correlation coefficient

It was also shown that greater scores in the Beck Depression Inventory were obtained by subjects who, due to diabetes, required the help of other people, in contrast to subjects not requiring such support $(p<0.001)$.

The obtained results of our own research also showed that greater severity of depressive disorders was present in people who did not comply with the rules of conduct in diabetes, compared to patients who followed these recommendations ( $p=0.016$ ). Another statistically significant correlation in this area concerned the severity of depressive disorders and difficulty in foot care - greater severity of these disorders occurred among people who had more difficulty in foot care in accordance with applicable guidelines $(p=0.041)$.

Patients who to a greater extent felt the effects of diabetes on psychological wellbeing scored more higher the Beck Depression Inventory than those who did not confirm such effects ( $p<0.001)$.

The last statistically significant correlation was confirmed between the source of support and the severity of depressive disorders. A greater severity of depressive disorders occurred among people who did not confirm receiving support from their spouse or partner in comparison with respondents who declared such support $(p=0.014)$. The relationships obtained are illustrated in Table 2.

\section{DISCUSSION}

The issue of the occurrence of depressive disorders among patients with type 2 diabetes was undertaken in connection with epidemiological data showing the growing tendency of this type of diabetes [8], as well as with the wide occurrence of its subsequent after-effects [9]. Test results confirm the presence of depressive relationships in this group of patients $[10,11]$.

Available analyses confirm the possibility of using many tools for assessing depressive disorders [12]. The Beck Depression Inventory was used in this analysis. The received results show the occurrence of moderate depressive disorders among the surveyed patients. Similar intensification of depressive disorders occurred among people with type 2 diabetes participating in Kalka's [13] studies, concerning patients' quality of life and occurrence of depressive symptoms as well as their ways of coping with stress.

Scientific reports also confirmed the connection between sociodemographic variables and depressive disorders in people diagnosed with type 2 diabetes. Analysis of the mentioned relations was also undertaken in our own research. Increased severity of depressive symptoms was confirmed among professionally inactive people who determined their monthly income as insufficient or rather insufficient. There was no significant correlation between the severity of depressive disorders and other selected variables, such as: gender, age, marital status, place of residence, education, and source of income. For comparison, in the study conducted by Alajmani et al. [14] women, unemployed people, and those with lower level of education received a higher number of points in the Beck Depression Inventory, which meant a greater severity of depressive disorders. In their research, Sughra et al. [15] also showed that women, compared to men, presented a greater severity of depressive symptoms, but this difference was not statistically significant. Zhang et al. [16] published results confirming that loneliness, as 
opposed to being married, was associated with the intensification of depressive symptoms. Kurowska et al. [17], in turn, obtained results that confirmed that the unemployed and those receiving disability benefits had a greater severity of depressive symptoms. The research published by Sopjani et al. [18] also showed that variables such as female sex, lower level of education, and living in rural areas were correlated with the severity of depressive disorders.

Diabetes, as a chronic disease, requires taking many actions in the field of self-control and self-care. The need for constant self-monitoring and compliance with medical recommendations may cause fatigue, nervousness, growing frustration, or anger. In some patients it promotes low self-esteem and even the development of depressive disorders [19]. Patients participating in the study also confirmed that diabetes had an impact on their mental wellbeing. Reactions and emotions after hearing a diagnosis of a chronic disease can be very different. They reflect both the acceptance and lack of acceptance of the disease [20], as well as anxiety, stress, and depressive disorders [2]. The obtained results of our own research showed significant positive correlations between the severity of depressive symptoms and the reaction after hearing the diagnosis. People participating in the study felt, among others: anxiety, fear, terror, or nervousness and uncertainty. However, only the feeling of uncertainty after being diagnosed with diabetes was related to the severity of depressive disorders.

A number of analyses show how important the problem of depressive disorders occurring among people with diabetes is today. Lerman et al. [21] in their studies proved that non-compliance with medical recommendations was associated with the occurrence of depressive symptoms. Park et al. [22] published results indicating correlation between a greater severity of depressive symptoms and noncompliance with diet. In turn, Sopjani et al. [18] in their study did not receive results confirming the relationship between the severity of the above disorders and diet. Of note, the meta-analysis carried out by Bai et al. [23] confirmed that insulin treatment was associated with a risk of depressive disorders. The authors' own research showed that patients who had more difficulty with foot care were characterised by significantly greater severity of depression. This important correlation prompts the reflection that professionals dealing with patient care should be more sensitive to the need to assess the knowledge and skills of patients with diabetes, especially in terms of necessary care activities and restrictions that cause difficulties in their performance.

Moreover, the lack of a spouse's or partner's support declared by the respondents significantly correlated with the severity of depressive disorders. In their study, Michalska-Leśniewicz and Gruszczyński [24] reported that remaining in a relationship that gives a sense of happiness is a factor that allows people to struggle with various life situations, including illness. However, the absence of someone who is close to you contributes to negative self-esteem and is a predisposing factor for depression. Spouses are usually the first to provide support in difficult situations. The relationships with siblings, family, or friends are not a real replacement for the relationship with the spouse and cannot be a buffer against stress and depression. Such conclusions are formulated, for example, by Rad et al. [25] in their research metaanalysis. Habtewold et al. [26] also state that the lack of social support may be an important risk factor for depression. It seems reasonable to assess patients' support resources among relatives and, in the case of its absence, to identify and provide alternative sources of support. The interdisciplinary team, within its competence, is also prepared to provide support in various dimensions.

Due to numerous analyses confirming the presence of depressive symptoms among people suffering from type 2 diabetes, the conclusion that there is a need for screening research in this direction can be drawn. The team led by Joseph et al. [27] confirmed such a possibility and at the same time proved that it would allow for the provision of quick and professional help to patients. According to Joseph et al., each member of the interdisciplinary team can carry out screening research. Obviously, it is associated with the need for professionals to constantly deepen their knowledge about depression itself and its increased risk among diabetics. Based on their own and their colleagues' meta-analysis of scientific reports, Khaledi et al. [28] also emphasised the need for screening in the field of depressive disorders and risk factors among patients with diabetes.

\section{CONCLUSIONS}

In connection with the results of our own research, it seems necessary to take actions aimed at sensitising interdisciplinary teams to the risk of depressive disorders among patients with type 2 diabetes.

Early recognition of depressive disorder symptoms will enable action to be taken in order to prevent their aggravation and provide holistic care to patients.

The presented results are fragments of research carried out as a part of statutory project

No. K/ZDS/007059: "Occurrence of depressive disorders in people with type 2 diabetes aged 35-64".

\section{Disclosure}

The authors declare no conflict of interest. 


\section{References}

1. Polskie Towarzystwo Diabetologiczne. Zalecenia kliniczne dotyczące postępowania u chorych na cukrzycę. Diabetologia Praktyczna 2018; 4: 1-94

2. Muciek K, Szewczyk L. Stan wyrównania metabolicznego a reakcje lękowe pacjentów z cukrzycą typu 2. Aspekty Zdrowia i Choroby 2018; 3: 7-22.

3. Wojtaszek M, Król M, Ozga D, et al. Próba określenia determinantów wystąpienia i nasilenia depresji u chorych na cukrzycę w populacji polskiej - doniesienie wstępne. Diabetologia Praktyczna 2016; 2: 163-169.

4. Osińska M, Kazberuk A, Celińska-Janowicz K, et al. Depresja choroba cywilizacyjna XXI wieku. Geriatria 2017; 11: 123-129.

5. Wilczek-Rużyczka E. Opieka w wybranych zespołach zaburzeń psychicznych - Opieka nad pacjentem z zaburzeniami depresyjnymi. In: Wilczek-Rużyczka E (ed.). Podstawy pielęgniarstwa psychiatrycznego. Wyd. 2. PZWL, Warszawa 2019; 119-129.

6. Tobiasz-Adamczyk B. Choroba - wyzwanie dla rodziny. Wybrane aspekty przeżywania choroby przez rodzinę. In: Szluz B (ed.). Doświadczanie choroby w rodzinie. Wydawnictwo Uniwersytetu Rzeszowskiego, Rzeszów 2019; 13-19.

7. Parnowski T, Jernajczyk W. Inwentarz Depresji Becka w ocenie osób zdrowych i chorych na choroby afektywne (ocena pilotażowa). Psychiatria Polska 1977; 11: 417-425.

8. Bauer M. Burden of disease of diabetes mellitus typ-2 in Austria. Value Health 2015; 18: A619.

9. Leśniowska J, Schubert A, Wojna M, et al. Costs of diabetes and its complications in Poland. Eur J Health Econ 2014; 15: 653-660.

10. Réus GZ, Dos Santos MAB, Strassi AP, et al. Pathophysiological mechanisms involved in the relationship between diabetes and major depressive disorder. Life Sci 2017; 183: 78-82.

11. Elaaty TAA, Ismail AA, Sheshtawy HA, et al. Assessment of comorbid mild cognitive impairment and depression in patients with type 2 diabetes mellitus. Diabetes Metab Syndr 2019; 13: 1759-1764.

12. de Joode JW, van Dijk SEM, Walburg FS, et al. Diagnostic accuracy of depression questionnaires in adult patients with diabetes: a systematic review and meta-analysis. PLoS One 2019; 14: e0218512.

13. Kalka D. Poczucie jakości życia a objawy depresji i sposoby radzenia sobie ze stresem u osób z cukrzycą typu 2 - doniesienie wstępne. Psychiatria Polska 2014; 48: 931-940.

14. Alajmani DSA, Alkaabi AM, Alhosani MW, et al. Prevalence of undiagnosed depression in patients with type 2 diabetes. Front Endocrinol 2019; 10: e020768.

15. Sughra U, Imran M. Co-morbid depression in individuals with type 2 diabetes mellitus. J Pak Med Assoc 2018; 68: 109-111.

16. Zhang $\mathrm{W}, \mathrm{Xu} \mathrm{H}$, Zhao S, et al. Prevalence and influencing factors of co-morbid depression in patients with type 2 diabetes mellitus: a General Hospital based study. Diabetol Metab Syndr 2015; 7: 60.

17. Kurowska K, Strzesak E, Głowacka M, et al. Depresyjność a poczucie koherencji u osób z rozpoznaniem typu 2 cukrzycy. Psychogeriatria Polska 2009; 6: 1-7.

18. Sopjani I, Vehapi S, Gorani D, et al. The relation between depressive symptoms and self-care in patients with diabetes mellitus type 2 in Kosovo. Med Arch 2016; 70: 425-428.

19. Dąbrowska A, Jurkowska B, Nowicki G, et al. Ocena wybranych elementów psychicznej jakości życia pacjentów leczonych z powodu cukrzycy typu 2. Curr Probl Psych 2012; 13: 128-133.

20. Pantlinowska D, Antczak A. Wpływ akceptacji choroby na jakość życia pacjentów z cukrzycą typu 2. Innowacje w Pielęgniarstwie i Naukach o Zdrowiu 2016; 4: 32-39.
21. Lerman I, Lozano L, Villa AR, et al. Psychosocial factors associated with poor diabetes selfcare management in a specialized center in Mexico City. Biomed Pharmacother 2004; 58: 566-570.

22. Park H, Hong Y, Lee $\mathrm{H}$, et al. Individuals with type 2 diabetes and depressive symptoms exhibited lower adherence with self-care. J Clin Epidemiol 2004; 57: 978-984.

23. Bai X, Liu Z, Yan D. The assocation between insulin therapy and depression in patients with type 2 diabetes mellitus: a meta-analysis. BMJ Open 2018; 8: e020062.

24. Michalska-Leśniewicz M, Gruszczyński W. Czynniki psychologiczne w depresji. Psychiatria 2010; 7: 97-103.

25. Rad GS, Bakht LA, Feizi A, et al. Importance of social support in diabetes care metaanaliza. J Educ Helath Promo 2013; 2: 62.

26. Habtewold TD, Alemu SM, Haile YG. Sociodemographic, clinical, and psychosocial factors associated with depression among type 2 diabetic outpatients in Black Lion General Specialized Hospital, Addis Ababa, Ethiopia: a cross-sectional study. BMC Psychiatry 2016; 16: 103.

27. Joseph LM, Berry DC, Jessup A, et al. Implementing and feasibility testing depression screening using the electronic medical record for patients with type 2 diabetes admitted to the hospital. Nurs Open 2018; 6: 30-38.

28. Khaledi M, Haghighatdoost F, Feizi A, et al. The prevalence of comorbid depression in patients with type 2 diabetes: an updated systematic review and meta-analysis on huge number of observational studies. Acta Diabetol 2019; 56: 631-650. 